\title{
Isolation and characterization of homoisoflavonoids from Scilla persica HAUSSKN
}

\author{
Salar Hafez-Ghoran', Pouneh Ebrahimi, ${ }^{1, *}$, Hossein Mighani1, Soudabeh Saeidnia² \\ ${ }^{1}$ Department of Chemistry, Faculty of Sciences, Golestan University, Gorgan, Iran, ${ }^{2}$ Medicinal Plants Research Center, Faculty \\ of Pharmacy, Tehran University of Medical Sciences, Tehran, Iran
}

\begin{abstract}
Medicinal plants have many traditional claims including the treatment of ailments of infectious origin. In the evaluation of traditional claims, scientific research is extremely important. In this study, five homoisoflavonoids named 3-(4'-hydroxybenzylidene)-5,7-dihydroxy-6-methoxychroman4-one(Autumnalin),3-(4'-hydroxybenzyl)-5,7-dihydroxy-6-methoxychroman-4-one (3,9-dihydroautumnalin), 3-(3', 4'-dihydroxybenzyl)-5,8-dihydroxy-7-methoxychroman-4-one, 3-(3',4'dihydroxybenzylidene)-5,8-dihydroxy-7-methoxychroman-4-one and 3-(3',4'-dihydroxybenzylidene)5,7-dihydroxy-6-methoxychroman-4-one, were isolated from the bulbs of the plant Scilla persica HAUSSKN. Their structures were established on the basis of extensive spectroscopic analyses such as NMR, MS, IR and UV.
\end{abstract}

Uniterms: Scilla persica HAUSSKN/phytochemistry. Homoisoflavonoids/isolation. Homoisoflavonoids/ isolation. Medicinal plants.

\begin{abstract}
Plantas medicinais apresentam muitas atribuições tradicionais, incluindo o tratamento de doenças de origem infecciosa. A pesquisa científica é extremamente importante na avaliação dos usos tradicionais. Neste estudo, cinco homoisoflavonóides: 3-(4'-hidroxibenzilideno)-5,7-diidroxi-6-metoxicroman-4ona(autumnalina), 3-(4'-hidroxibenzil)-5,7-diidroxi-6- metoxicroman-4-ona (3,9-diidro-autumnalina), 3-(3',4'-diidroxibenzil)-5,8-diidroxi-7- metoxicroman-4-ona, 3-(3',4'-diidroxibenzilideno)-5,8diidroxi-7- metoxicroman-4-ona e 3-(3',4'-diidroxibenzilideno)-5,7-diidroxi-6- metoxicroman-4-ona foram isolados dos bulbos da planta Scilla persica HAUSSKN. Suas estruturas foram estabelecidas com base na extensa análise espectroscópica, como RMN, EM, IV e UV.
\end{abstract}

Unitermos: Scilla persica HAUSSKN/fitoquímica. Homoisoflavonóides/separação. Homoisoflavonóides/ isolamento. Plantas medicinais.

\section{INTRODUCTION}

Over the years, natural medicines, especially medicinal herbs, were considered for the treatment of a variety of ailments. The ingredients contained in these plants are used in the pharmaceutical industry because of their disinfecting properties (Amin, 1991; Volak, Stodola, 1995; Yasuda et al., 2013). Scilla persica HAUSSKN is a perennial plant that belongs to the Liliaceae family. The bulb of this plant is used as a foodstuff, a traditional medicine that increases blood circulation, as an anti-

*Correspondence: Pouneh Ebrahimi. Department of Chemistry. Faculty of Sciences. Golestan University. P. O. Box 155. Post code 4913815759. Gorgan, Iran.E-mail: epouneh@yahoo.com; p.ebrahimi@gu.ac.ir inflammatory agent as well as an analgesic (Crouch, Bangani, Mulholland, 1999). This plant has a small white bracteole that includes one or two high-centered flowers (10-13 flowers), with two to four leaf sheathes. Its petals are bluish in color, standing erect with inflorescence or a cluster of flowers. The axis of their flowers is usually single and rarely dual. In Iran, the habitat of this plant exists in the West Azerbaijan, Khorram Abad, Alvand, Hamedan, Qasr Shirin, Sanandaj and the Mountains of Rzab (Mobin, 1975; Rahimi, Aghaalinejad, Arslana, 2012).

According to phytochemical studies performed on the Scilla species, the chemical compounds reported contain alkaloids, cardiac glycosides, stilbenes (Bangani, Crouch, Mulholland, 1999; Crouch, Bangani, Mulholland, 1999; Kato et al., 2007; Nishida et al., 
2008; Ono et al., 2013; Silayo, Ngadjui, Abegaz, 1999) and specially homoisoflavanones (Bangani, Crouch, Mulholland, 1999; Famuyiwa et al., 2012; Ghoran et al., 2014; Heller, Tamm, 1981; Kouno, Komori, Kawasaki, 1973; Shim et al., 2004). Homoisoflavonoids were reported to be responsible for the biomedical activities of these plants, such as antibacterial, antifungal, antiallergic, antioxidant, cytotoxic and anti-angiogenic activities. They also inhibit in-vitro the growth and sporogenesis of several microorganisms (Heller, Tamm, 1981; Kouno, Komori, Kawasaki, 1973; Mighani, Ebrahimi, 2014; Nishida et al., 2013; Shim et al., 2004). Stilbenes of scilla bulbs has been used in the treatment of asthma, coughs, bronchitis, heart disease (adjusted HR), rheumatism, diuretic, expectorant (Gupta, Raina, 2001), internal tumors, dilate blood vessels, anti-allergic and anti-mutagenic (Dias, Graça, Gonçalves, 2000; Yasuda et al., 2013). In traditional Iranian medicine, the bulbs of scilla herb were used as the antidote, activator of blood circulation and also the treatment of eczema. It can also treat swelling and abscesses (Winnicka, Bielawski, Bielawski, 2006). Studies have shown that the bulb of Scilla natalensis has anti-cancer properties, antibacterial properties; it kills worms (intestinal parasite) and also prevents the formation of cancerous agents. Also sodden these plants are used for the treatment of abscesses (Chinthala, Chinde, 2014; Koorbanally et al., 2007). There are reports that bulbs of Scilla are used for gynecological treatment of menstrual pains and to facilitate delivery in childbirth (Gerstner, 1941; Hutchings, 1989; 1996). Decoctions are also taken as enemas for female fertility and to enhance male potency and libido (Gerstner, 1941).

In a previous paper (Ghoran et al., 2014), we reported the isolation and structural

elucidation of a new homoisoflavonoid from the $\mathrm{CHCl} 3$ extract of fresh bulbs of $S$. persica along with MTT cytotoxicity assay on AGS and WEHI-164 cancerous cell lines. As part of an ongoing study of this plant, we described the isolation and structural characterization of five other homoisoflavonoids from the $\mathrm{CHCl} 3$ extract from the bulbs of the plant Scilla persica HAUSSKN. Their structures were identified on the basis of extensive spectroscopic analyses such as NMR, MS, IR and UV.

\section{MATERIAL AND METHODS}

\section{General experimental procedures}

An Electrothermal Melting Point Apparatus was used to determine precise melting points. UV and IR spectra were recorded by a Shimadzu UV-PC 2501 and Perkin- Elmer spectrophotometer, respectively. NMR spectra were also obtained in either CD3OD or DMSO-d6 using a Bruker AV-500 instrument with TMS as the internal standard. EIMS were also recorded with a VG-Autospec-3000 spectrometer. HREIMS were recorded with a Thermo Fisher Finnegan MAT 95 XP instrument. Column chromatography (CC) was carried out using silica gel (70-230 and 230-400 mesh; E-Merck, Darmstadt, Germany). Aluminum sheets precoated with silica gel $60 \mathrm{~F} 254(10 \times 10 \mathrm{~cm}, 0.2 \mathrm{~mm}$ thick; E-Merck) were applied for TLC to check the purity of the compounds and were observed under UV light (254 and $365 \mathrm{~nm}$ ) followed by anisaldehyde as the spray reagent and then it was heated.

\section{Plant material}

The plant used for the present study (S. persica) was collected and identified in March 2011 from the village of Valliv (Sardasht, West Azerbaijan Province, Iran) at an altitude of 1700-1800 m. A voucher specimen (6334) is deposited in the Herbarium of Agricultural Research Center and Natural Resources of Sari, Iran.

\section{Phytochemical screening (qualification tests)}

The tests were performed to find the presence of the bioactive chemical constituents, such as alkaloids, anthraquinones, flavonoids, glycosides, reducing sugar, saponins, tannins, terpenoids and steroids (Table I) (Iyengar, 1981; Savithramma, Rao, Suhrulatha, 2011; Siddiqui, Ali, 1997).

\section{Extraction and isolation}

The bulbs of $S$. persica $(400 \mathrm{~g})$ were crashed and extracted with EtOAc $(3 \times 2.5 \mathrm{~L})$ at room temperature for $24 \mathrm{~h}$. The combined extracts were concentrated under reduced pressure. Then the crude extract of the bulbs were subjected to column chromatography and eluted with n-hexane:EtOAc: $\mathrm{MeOH}$, in the order of increasing polarity $(70: 30: 0,60: 40: 0,50: 50: 0,40: 60: 0,20: 80: 0$, $0: 100: 0,0: 80: 20,0: 70: 300: 60: 40$ and 0:50:50 (v/v), respectively) to separate different fractions. Fraction A (190 mg) was further separated by Sephadex LH20 column chromatography and eluted with $\mathrm{MeOH}$ to give $\mathbf{1}(7 \mathrm{mg})$ (SILAYO et al., 1999) and $\mathbf{2}(18 \mathrm{mg}$ ) (Silayo, Ngadjui, Abegaz, 1999). Repeated column chromatography of fraction $\mathbf{B}(210 \mathrm{mg})$ using a silica gel column and isocratic elution with $\mathrm{CHCl} 3: \mathrm{MeOH}$ 
8:2) afforded 3 (30 mg) (Adinolfi et al., 1989). Moreover fraction C (150 mg) gave two compounds $4(15 \mathrm{mg})$ and 5 (23 mg) (Mašterová et al., 1991) upon elution with MeOH on a Sephadex LH-20 column.

\section{RESULTS AND DISCUSSION}

Table I shows the results of phytochemical screening (qualification tests) on S. persica HAUSSKN. These results indicated that this plant contains flavonoids, glycosides, reducing sugars, saponins and tannins especially catecholic tannins and alkaloids. The bulb of this plant is void of terpenoids and steroids.

The spectroscopic and other physical data of the isolated compounds 1-5 were indicated below and details of ${ }^{1} \mathrm{H}$ and ${ }^{13} \mathrm{C}$-NMR spectroscopic data were also shown in Table II.

\section{3-(4'-Hydroxybenzylidene)-5, 7-dihydroxy-6-}

methoxychroman-4-one (1)

Yellowish powder with $\mathrm{C}_{17} \mathrm{H}_{14} \mathrm{O}_{6}$ molecular formula; mp 242-245 ${ }^{\circ} \mathrm{C}$; IR (KBr) $V_{\max }\left(\mathrm{cm}^{-1}\right) 3423(\mathrm{OH}), 1647$ $(\mathrm{C}=\mathrm{O}), 1510(\mathrm{C}=\mathrm{C}$ Ar $), 1458(-\mathrm{CH} 3), 1328,1173(\mathrm{C}-\mathrm{O})$; $\mathrm{UV}(\mathrm{MeOH}) \lambda_{\max }(\log \varepsilon) 197$ (4.80), 359 (4.25) nm; EIMS $\mathrm{m} / \mathrm{z}$ (rel. int.) $314[\mathrm{M}]^{+}$(89), 299 (25), 183 (15), 167 (55), 131 (24); ${ }^{1} \mathrm{H}$ and ${ }^{13} \mathrm{C}-\mathrm{NMR}$ spectroscopic data are shown in Table II.
3-(4'-Hydroxybenzyl)-5, 7-dihydroxy-6-

methoxychroman-4-one (2)

Yellowish plates from $\mathrm{CHCl}_{3}$ with $\mathrm{C}_{17} \mathrm{H}_{16} \mathrm{O}_{6}$ molecular formula; $\mathrm{mp} 198-200{ }^{\circ} \mathrm{C}$; IR $(\mathrm{KBr}) \mathrm{V}_{\max }\left(\mathrm{cm}^{-1}\right)$ $3356(\mathrm{OH}), 1638(\mathrm{C}=\mathrm{O}), 1609(\mathrm{C}=\mathrm{C}$ Ar. $), 1451(-\mathrm{CH} 3)$, 1265, 1153 (C-O); UV (MeOH) $\lambda_{\max }$ (log $\left.\varepsilon\right) 211$ (4.30), 293 (4.421) 320 (4.98) nm; EIMS m/z (rel. int.) $316[\mathrm{M}]^{+}$ (100), 301 (37), 283 (15), 265 (12), 210 (85), 109 (77); ${ }^{1} \mathrm{H}$ and ${ }^{13} \mathrm{C}$-NMR spectroscopic data are shown in Table II.

\section{3-(3', 4'-dihydroxybenzyl)-5, 8-dihydroxy-7-}

methoxychroman-4-one (3)

Yellow-Brown plates from $\mathrm{MeOH}$ with $\mathrm{C}_{17} \mathrm{H}_{16} \mathrm{O}_{7}$ molecular formula; mp 138-141 ${ }^{\circ} \mathrm{C}$; EIMS $(70 \mathrm{eV}) \mathrm{m} / \mathrm{z}$ (rel. int.) $332.0899\left([\mathrm{M}]^{+}\right.$; calc for $\left.\mathrm{C}_{17} \mathrm{H}_{16} \mathrm{O}_{7} 332.0896\right)$ (95), 210 (100), 195 (15), 183 (50), 167 (35), 149 (20), 123 (95); ${ }^{1} \mathrm{H}$ and ${ }^{13} \mathrm{C}-\mathrm{NMR}$ spectroscopic data are shown in Table II.

\section{3-(3', 4'-dihydroxybenzylidene)-5, 8-dihydroxy-7-}

methoxychroman-4-one (4)

Orange powder from $\mathrm{MeOH}$ with $\mathrm{C}_{17} \mathrm{H}_{14} \mathrm{O}_{7}$ molecular formula; $\mathrm{mp}: 233-237^{\circ} \mathrm{C}$; IR $(\mathrm{KBr}) \mathrm{V}_{\max }\left(\mathrm{cm}^{-1}\right)$ $3501(\mathrm{OH}), 3348$ (-CH Ar. and vin. Stretching), 1638 $(\mathrm{C}=\mathrm{O}), 1568(\mathrm{C}=\mathrm{C}$ Ar. $), 1521(\mathrm{C}=\mathrm{C}$ Ar. $), 1477(\mathrm{C}=\mathrm{C}$ Ar. $)$, 1436 (-CH3), 1264, 1089 (-C-O); UV (MeOH) $\lambda_{\max }(\log \varepsilon)$ 269 (4.19), 340 (shoulder) (4.30), 367 (4.29) nm; EIMS

TABLE I - Results of phytochemical screening tests on Scilla persica HAUSSKN

\begin{tabular}{|c|c|c|c|}
\hline $\begin{array}{l}\text { Type of Secondary } \\
\text { Metabolites }\end{array}$ & Methods & Observations & Result \\
\hline \multirow[t]{2}{*}{ Alkaloids } & Mayer's Test & A white yellowish precipitate & $\begin{array}{l}\text { No } \\
\text { Yes }\end{array}$ \\
\hline & Dragendorff's Test & A turbidity or orange precipitate & \\
\hline Anthraquinones & Bourne-Tragr Reaction & Formation of rose-pink color & No \\
\hline \multirow[t]{2}{*}{ Flavonoids } & Shinoda Test & A red solution & $\begin{array}{l}\text { Yes } \\
\text { Yes }\end{array}$ \\
\hline & Alkaline Reagent Test & A yellowish orange solution & \\
\hline Glycosides & Keller-Killiani Test & A reddish brown solution & Yes \\
\hline Reducing Sugars & Fehling's Test & $\begin{array}{l}\text { A green solution with fehling A } \\
\text { A brown solution with fehling B }\end{array}$ & $\begin{array}{l}\text { Yes } \\
\text { Yes }\end{array}$ \\
\hline Terpenoids & Libermann-Buchard Test & A red-violet solution & No \\
\hline Tannins & Ferric Chloride Test & $\begin{array}{l}\text { A blue solution for gallic tannins } \\
\text { A green-black solution for catecholic } \\
\text { tannins }\end{array}$ & $\begin{array}{l}\text { No } \\
\text { Yes }\end{array}$ \\
\hline Saponins & Froth Test & $\begin{array}{l}\text { Appearance of creamy miss of small } \\
\text { bubbles }\end{array}$ & Yes \\
\hline Steroids & Libermann-Buchard Test & A green bluish solution & No \\
\hline
\end{tabular}


(70 eV) m/z (rel. int.) $330.0909[\mathrm{M}]^{+} \mathrm{C}_{17} \mathrm{H}_{14} \mathrm{O}_{7}(100), 315$ (25), 183 (38), 169 (10), 168 (12), 167 (48), 149 (18), 148 (25), 147 (12); ${ }^{1} \mathrm{H}$ and ${ }^{13} \mathrm{C}$-NMR spectroscopic data are shown in Table II.

\section{3-(3', 4'-dihydroxybenzylidene)-5, 7-dihydroxy-6-} methoxychroman-4-one (5)

Orange crystals from $\mathrm{MeOH}$ with $\mathrm{C}_{17} \mathrm{H}_{14} \mathrm{O}_{7}$ molecular formula; $\mathrm{mp} 237-240^{\circ} \mathrm{C}$; IR $(\mathrm{KBr}) \mathrm{V}_{\max }\left(\mathrm{cm}^{-1}\right)$ 3497 (OH), 3343 (-CH Ar. and vin. Stretching), 1642 $(\mathrm{C}=\mathrm{O}), 1531$ (C=C Ar.), 1436 (-CH3), 1260, 1050 (-C-O); $\mathrm{UV}(\mathrm{MeOH}) \lambda_{\text {max }}(\log \varepsilon) 264$ (4.02), 384 (4.35) nm; EIMS $(70 \mathrm{eV}) \mathrm{m} / \mathrm{z}$ (rel. int.) $330.0910[\mathrm{M}]^{+} \mathrm{C}_{17} \mathrm{H}_{14} \mathrm{O}_{7}(100), 315$ (25), 183 (38), 169 (10), 168 (12), 167 (48), 149 (18), 148 (25), 147 (12); ${ }^{1} \mathrm{H}$ and ${ }^{13} \mathrm{C}$-NMR spectroscopic data are shown in Table II.

The isolated compounds 1-5 in this plant showed the presence of a $5-\mathrm{OH}$ group confirmed by ${ }^{1} \mathrm{H}-\mathrm{NMR}$ spectroscopy $\left(\delta_{O H}>11.5\right)$ in Table II.

As it can be seen in Figures 1, 4 and 5 compounds have the same mass and due to the position of $\mathrm{CH} 3$ and $-\mathrm{OH}$ substituents on ring $\mathrm{A}$ are different.

Compound 1: The spectroscopic and other physical data of compound 1 were found to be similar to those reported for autumnalin isolated from the bulbs of Eucomis autumnalis, Colchicum doerfleri and Scilla nervosa (Buckingham, 1993; Sidwell, Tamm, 1970; Silayo, Ngadjui, Abegaz, 1999).

Compound 2: Compound 2 exhibited spectral data very similar to those reported for eucomnalin (3,9-dihydroautumnalin), a compound isolated previously from Eucomis autumnalis (Tamm, 1972) and it was recently<smiles>[R4]c1cc(C=C2COc3c([R])c([R4])c(O)c(c3C)C2=O)ccc1O</smiles>

\begin{tabular}{c|cccc}
\multicolumn{1}{c}{} & $\mathrm{R}_{1}$ & $\mathrm{R}_{2}$ & $\mathrm{R}_{3}$ & $\mathrm{R}_{4}$ \\
\cline { 2 - 5 } $\mathbf{1}$ & $\mathrm{H}$ & $\mathrm{OH}$ & $\mathrm{OMe}$ & $\mathrm{H}$ \\
$\mathbf{4}$ & $\mathrm{OH}$ & $\mathrm{OMe}$ & $\mathrm{H}$ & $\mathrm{OH}$ \\
$\mathbf{5}$ & $\mathrm{H}$ & $\mathrm{OH}$ & $\mathrm{OMe}$ & $\mathrm{OH}$
\end{tabular}

reported from S. nervosa Silayo, Ngadjui, Abegaz, 1999). The ${ }^{1} \mathrm{H}-\mathrm{NMR}$ of compound $\mathbf{2}$ indicated a sharp singlet at $\delta_{H} 5.93 \mathrm{ppm}$ and it was assigned to $\mathrm{H}-8$ in compound 2. The ${ }^{13} \mathrm{C}-\mathrm{NMR}$ data is in complete agreement with the given structure (Agrawal, 1989). The location of the only methoxy signal observed in $\mathbf{2}$ was deduced to be at C-6 on the basis of the downfield resonance position of the methoxy carbon at $\delta_{C} 60.47 \mathrm{ppm}$ and the presence of a $\mathrm{C}-5 \mathrm{OH}$ group.

Compound 3: The B ring of 3-benzyl-4-chromanone 3 has two oxygenated functions. In fact, the base peak in the mass spectra of compound $\mathbf{3}$ was due to dihydroxytropylium fragment $(\mathrm{m} / \mathrm{z} 123)$. The peak $(\mathrm{m} / \mathrm{z}$ 183 ) in the mass spectrum of $\mathbf{3}$ also indicated that the $A$ ring has two hydroxyl and one methoxy group. The NMR signals of the hydroxyl proton, methoxy and methine protons in the A ring at $\delta_{\mathrm{H}} 11.83,3.82$ and $6.19 \mathrm{ppm}$, respectively, revealed that one hydroxyl group located at $\mathrm{C}-5$ while the methoxy group is at C-7. The chemical shifts of the A ring carbons are very similar to those of $\mathbf{2}$. Therefore the remaining hydroxyl group is linked at C-8.

Compound 4: The ${ }^{1} \mathrm{H}$ and ${ }^{13} \mathrm{C}-\mathrm{NMR}$ spectral data of compound $\mathbf{4}$ are identical with those previously described (Adinolfi et al., 1989; Mašterová et al., 1991).

Compound 5: Substitution of a methoxy group at C-6 in compound $\mathbf{5}$ was confirmed by losing methyl group giving a characteristic $[\mathrm{M}-15]^{+}$ion like those in 6-OMe flavones (Bowie, Cameron, 1966). This cleavage is followed in ring $\mathrm{A}$ by a gradual elimination of $\mathrm{CO}(\mathrm{m} / \mathrm{z} 287)$ and $\mathrm{H}_{2} \mathrm{O}$ ('ortho effect', $\left.\mathrm{m} / \mathrm{z} 269\right)$. The latter experiment also led to the assignment of carbon<smiles></smiles>

\begin{tabular}{c|cccc}
\multicolumn{1}{c}{} & $\mathrm{R}_{1}$ & $\mathrm{R}_{2}$ & $\mathrm{R}_{3}$ & $\mathrm{R}_{4}$ \\
\cline { 2 - 5 } $\mathbf{2}$ & $\mathrm{H}$ & $\mathrm{OH}$ & $\mathrm{OMe}$ & $\mathrm{H}$ \\
$\mathbf{3}$ & $\mathrm{OH}$ & $\mathrm{OMe}$ & $\mathrm{H}$ & $\mathrm{OH}$
\end{tabular}

FIGURE 1 - Chemical structures of the isolated homoisoflavonoids 1-5 from bulbs of the plant Scilla persica HAUSSKN 
TABLE II - ${ }^{1} \mathrm{H}$ and ${ }^{13} \mathrm{C}-\mathrm{NMR}$ chemical shifts ( $\delta / \mathrm{ppm}$ ) of compounds $1-5$ in $\mathrm{CD}_{3} \mathrm{OD}^{\mathrm{a}}$ and DMSO- $\mathrm{d}_{6}^{\mathrm{b}}$ as the solvents $(500 \mathrm{MHz}$ for $\delta_{\mathrm{H}}$ and $125 \mathrm{MHz}$ for $\delta_{\mathrm{C}}$ )

\begin{tabular}{|c|c|c|c|c|c|c|c|c|c|c|}
\hline \multirow[t]{2}{*}{ position } & \multicolumn{2}{|c|}{$1^{\mathrm{a}}$} & \multicolumn{2}{|c|}{$2^{\mathrm{b}}$} & \multicolumn{2}{|c|}{$3^{\mathrm{b}}$} & \multicolumn{2}{|c|}{$4^{b}$} & \multicolumn{2}{|c|}{$5^{\mathrm{b}}$} \\
\hline & $\begin{array}{c}\delta_{\mathrm{H}} \\
(\mathrm{J} \text { in } \mathrm{Hz}) \\
\end{array}$ & $\delta_{\mathrm{c}}$ & $\begin{array}{c}\delta_{\mathrm{H}} \\
(\mathrm{J} \text { in } \mathrm{Hz}) \\
\end{array}$ & $\delta_{\mathrm{c}}$ & $\begin{array}{c}\delta_{\mathrm{H}} \\
(\mathrm{J} \text { in Hz) } \\
\end{array}$ & $\delta_{\mathrm{c}}$ & $\begin{array}{c}\delta_{\mathrm{H}} \\
(\mathrm{J} \text { in Hz) }\end{array}$ & $\delta_{\mathrm{c}}$ & $\begin{array}{c}\delta_{\mathrm{H}} \\
(\mathrm{J} \text { in } \mathrm{Hz}) \\
\end{array}$ & $\delta_{\mathrm{c}}$ \\
\hline $\begin{array}{l}2 \mathrm{a} \\
2 \mathrm{~b}\end{array}$ & $5.28, \mathrm{~d}(1.5)$ & 67.35 & $\begin{array}{c}4.21, \mathrm{dd} \\
(11.5,4.5) \\
4.03, \mathrm{dd} \\
(11.25,8.5)\end{array}$ & 69.37 & $\begin{array}{c}4.28, \mathrm{dd} \\
(4.3,11.3) \\
4.11, \mathrm{dd} \\
(3.9,7.6)\end{array}$ & 69.35 & $5.32, \mathrm{~d}(1.5)$ & 67.20 & $5.33, \mathrm{~d}(1.6)$ & 67.10 \\
\hline 3 & & 125.56 & $2.92(\mathrm{~m})$ & 46.11 & $2.92(\mathrm{~m})$ & 46.51 & & 126.41 & & 126.14 \\
\hline 4 & & 185.75 & & 198.99 & & 199.18 & & 185.26 & & 184.82 \\
\hline $4 a$ & & 102.48 & & 101.76 & & 102.18 & & 102.40 & & 101.90 \\
\hline 5 & & 159.23 & & 155.80 & & 157.40 & & 156.73 & & 156.06 \\
\hline 6 & & 126.80 & & 128.52 & $6.19(\mathrm{~S})$ & 93.03 & $6.21(\mathrm{~S})$ & 92.89 & & 129.28 \\
\hline 7 & & 159.40 & & 159.88 & & 156.44 & & 157.24 & & 159.47 \\
\hline 8 & $5.92(\mathrm{~S})$ & 94.73 & $5.93(\mathrm{~S})$ & 95.16 & & 126.81 & & 125.20 & $5.90(\mathrm{~S})$ & 94.82 \\
\hline $8 a$ & & 155.97 & & 158.38 & & 148.58 & & 147.05 & & 157.00 \\
\hline $\begin{array}{l}9 a \\
9 b\end{array}$ & $7.73(\mathrm{~S})$ & 137.21 & $\begin{array}{c}2.99, \mathrm{dd} \\
(14,5) \\
2.57, \mathrm{dd} \\
(13.8,9.5)\end{array}$ & 31.60 & $\begin{array}{c}2.93, \mathrm{dd} \\
(5.7,10.4) \\
2.54, \mathrm{dd} \\
(10.8,13.5)\end{array}$ & 31.85 & $7.62(\mathrm{~S})$ & 137.34 & $7.65(\mathrm{~S})$ & 137.8 \\
\hline 1 ' & & 129.33 & & 129.48 & & 129.20 & & 125.23 & & 124.90 \\
\hline $2^{\prime}$ & $7.21, \mathrm{~d}(8)$ & 132.32 & 7.01, d (9.5) & 130.42 & $6.62, \mathrm{~d}(2.1)$ & 116.79 & $6.84(\mathrm{~S})$ & 117.79 & $6.87(\mathrm{~S})$ & 117.76 \\
\hline $3^{\prime}$ & $6.88, \mathrm{~d}(9)$ & 115.58 & $6.68, \mathrm{~d}(8.5)$ & 115.71 & & 145.62 & & 145.45 & & 145.20 \\
\hline 4' & & 159.94 & & 156.22 & & 144.28 & & 148.07 & & 147.85 \\
\hline $5^{\prime}$ & $6.88, \mathrm{~d}(9)$ & 115.58 & $6.68, \mathrm{~d}(8.5)$ & 115.71 & $6.66, \mathrm{~d}(8.1)$ & 116.05 & $6.86, \mathrm{~d}(3.5)$ & 115.92 & $6.89, \mathrm{~d}(8.2)$ & 115.91 \\
\hline $6^{\prime}$ & $7.21, \mathrm{~d}(8)$ & 132.32 & 7.01, d (9.5) & 130.42 & $\begin{array}{c}6.48, \mathrm{dd} \\
(2.0,8.05)\end{array}$ & 120.15 & $\begin{array}{l}6.81, \mathrm{dd} \\
(2,8.5)\end{array}$ & 123.64 & $\begin{array}{c}6.79, \mathrm{dd} \\
(1.8,8)\end{array}$ & 123.55 \\
\hline $5-\mathrm{OH}$ & $12.9(\mathrm{~S})$ & & $12.22(\mathrm{~S})$ & & $11.83(\mathrm{~S})$ & & $12.48(\mathrm{~S})$ & & $12.8(\mathrm{~S})$ & \\
\hline C6-OMe & $3.81(\mathrm{~S})$ & 59.95 & $3.65(\mathrm{~S})$ & 60.47 & & & & & $3.68(\mathrm{~S})$ & 59.83 \\
\hline $\mathrm{C} 7-\mathrm{OMe}$ & & & & & $3.82(\mathrm{~S})$ & 56.58 & $3.83(\mathrm{~S})$ & 56.15 & & \\
\hline
\end{tabular}

resonances in this part of the molecule. These results are in good agreement with ${ }^{13} \mathrm{C}$-NMR data of the 3, 9-dihydro derivative of 5 (Purushothaman et al., 1982).

\section{CONCLUSION}

Scilla persica HAUSSKN is an edible plant that is used in traditional medicine to treat eczema and to relieve constipation, but, so far, no reports have been documented with evidence of its compounds. The results of phytochemical screening of this plant showed the presence of flavonoids, glycoside, tannin and saponin. The presence of flavonoids in this plant is probably responsible for the antibacterial effects. In this study, five homoisoflavonoids were isolated from bulbs of the plant Scilla persica HAUSSKN and their structures were identified using spectroscopic analyses such as NMR, MS, IR and UV. The spectroscopic and other physical data of isolated compounds were found to be similar to those reported for autumnalin isolated from the bulbs of Eucomis autumnalis, Colchicum doerfleri and Scilla nervosa.

\section{CONFLICTS OF INTEREST}

The authors report no conflicts of interest for the present study.

\section{REFERENCES}

ADINOLFI, M.; AQUILA, T.; BARONE, G.; LANZETTA, R.; PARRILLI, M. Homoisoflavanones from Bellevalia romana. Phytochemistry, v.28, n.11, p.3244-3246, 1989. 
AGRAWAL, P. Carbon-13 NMR of flavonoids. Amesterdam: Elsevier, 1989. v.39, p.256.

AMIN, G. Traditional pharmaceutical plants of Iran. Tehran: Iranian Ministry of Health \& Medical Education Publications, 1991. v.1, p.8-10.

BANGANI, V.; CROUCH, N.R.; MULHOLLAND, D.A. Homoisoflavanones and stilbenoids from Scilla nervosa. Phytochemistry, v.51, n.7, p.947-951, 1999.

BOWIE, J.; CAMERON, D. Electron impact studies. II. Mass spectra of quercetagetin derivatives. Aust. J. Chem., v.19, n.9, p.1627-1635, 1966.

BUCKINGHAM, J. Dictionary of natural products. Boca Raton, FL: CRC Press, 1993. 8584 p.

CHINTHALA, Y.; CHINDE, S. Anticancer active homoisoflavone from the underground bulbs of Ledebouria hyderabadensis. Pharm. Res., v.6, n.4, p.303, 2014.

CROUCH, N.R.; BANGANI, V.; MULHOLLAND, D.A. Homoisoflavanones from three South African: Scilla species. Phytochemistry, v.51, n.7, p.943-946, 1999.

DIAS, C.; GRAÇA, J.B.; GONÇALVES, M.L. Scilla maderensis, TLC screening and positive inotropic effect of bulb extracts. J. Ethnopharmacol., v.71, n.3, p.487-492, 2000 .

FAMUYIWA, S.O.; SICHILONGO, K.F.; YEBOAH, S.O.; ABEGAZ, B.M. Homoisoflavonoids from the inter-bulb surfaces of Scilla nervosa subsp.rigidifolia. Phytochem. Lett., v.5, n.3, p.591-595, 2012.

GERSTNER, J. A preliminary check list of Zulu names of plants: With short notes. J. Bantu Studies, v.15, n.1, p.277301, 1941.

GHORAN, S.H.; SAEIDNIA, S.; BABAEI, E.; KIUCHID, F.; DUSEKE, M.; EIGNERE, V.; KHALAJI, A.D.; SOLTANI, A.; EBRAHIMI, P.; MIGHANI, H. Biochemical and biophysical properties of a novel homoisoflavonoid extracted from Scilla persica HAUSSKN. Bioorg. Chem., v.57, p.51-56, 2014.

GUPTA, L.; RAINA, R. Antioxidant property of the bulb of Scilla indica. Curr. Sci., v.80, n.10, p.1267, 2001.
HELLER, W.; TAMM, C. Homoisoflavanones and biogenetically related compounds. Progress in the Chemistry of Organic Natural Products. Springer, 1981. p.105-152.

HUTCHINGS, A. A survey and analysis of traditional medicinal plants as used by the Zulu; Xhosa and Sotho. Bothalia, v.19, n.1, p.112-123, 1989.

HUTCHINGS, A. Zulu medicinal plants: an inventory. Pietermarizburg: University of Natal Press, 1996. 464 p.

IYENGAR, M.A. Study of crude drugs. 8.ed. Manipal India: Manipal College of Pharmaceutical Sciences, 1995. p.2.

KATO, A. KATO, N.; ADACHI, I.; HOLLINSHEAD, J.; FLEET, G.W.J.; KURIYAMA, C.; IKEDA, K.; ASANO, N.; NASH, R.J. Isolation of glycosidase-inhibiting hyacinthacines and related alkaloids from Scilla socialis. J. Nat. Prod., v.70, n.6, p.993-997, 2007.

KOORBANALLY, C.; SEWJEE, S.; MULHOLLAND, D.A.; CROUCH, N.R.; DOLD, A. Homoisoflavanones from Pseudoprospero firmifolium of the monotypic tribe Pseudoprospereae (Hyacinthaceae: Hyacinthoideae). Phytochemistry, v.68, n.22, p.2753-2756, 2007.

KOUNO, I.; KOMORI, T.; KAWASAKI, T. Zur struktur der neuen typen homo-isoflavanone aus bulben von scilla scilloides druce. Tetrahedron Lett., v.14, n.46, p.4569-4572, 1973.

MAŠTEROVÁ, I.; GRANCAIOVA, Z.; UHRINOVA, S.; SUCHY, V.; UBIK, K.; NAGY, M. Flavonoids in flowers of Calendula officinalis L. Chem. Papers, v.45, n.1, p.105108, 1991.

MIGHANI, H.; EBRAHIMI, P. In-Vitro anti-bacterial activity of chloroform, ethyl acetate and hydroalcoholic extracts of Scilla persica Hausskn. J. Gorgan Un. Med. Sci., v.16, n.1, p.106-113, 2014.

MOBIN, S. Iranian plants, flora of vascular plants. 2.ed. Tehran: University Press, 1980. v.1, p.163-165.

NISHIDA, Y.; ETO, M.; MIYASHITA, H.; IKEDA, T.; YAMAGUCHI, K.; YOSHIMITSU, H.; NOHARA, T.; ONO, M. A new homostilbene and two new homoisoflavones from the bulbs of Scilla scilloides. Chem. Pharm. Bull., v.56, n.7, p.1022-1025, 2008. 
NISHIDA, Y.; WADA, K.; TOYOHISA, D.; TANAKA, T.; ONO, M.; Yasuda, SH. Homoisoflavones as the antioxidants responsible from bulbs of Scilla scilloides. Nat. Prod. Res., v.27, n.24, p.2360-2362, 2013.

ONO, M.; OCHIAI, T.; YASUDA, SH.; NISHIDA, Y.; TANAKA, T.; OKAWA, M.; KINJO, J.; YOSHIMITSU, H.; NOHARA, T. Five new nortriterpenoid glycosides from the bulbs of Scilla scilloides. Chem. Pharm. Bull.,v.61, n.5, p.592-598, 2013.

PURUSHOTHAMAN, K.; KALYANI, K.; SUBRAMANIAM, K.; SHAUMUGHANATHAN, S.P. Structure of bonducellinNew homoisoflavone from Caesalpinia bonducella. Indian J. Chem., v.21B, p.383-386, 1982.

RAHIMI, A.; AGHAALINEJAD, M.; ARSLANA, N. Geophytes of sulduz region, west azerbayjan province, Iran and their characteristics. Pure App. Biol., v.1, n.1, p.18-21, 2012.

SAVITHRAMMA, N.; RAO, M.L.; SUHRULATHA, D. Screening of medicinal plants for secondary metabolites. Middle-East J. Sci. Res., v.8, n.3, p.579-584, 2011.

SHIM, J. S.; KIM, J.H.; LEE, J.; KIM, S.N.; KWON, H.J. Antiangiogenic activity of a homoisoflavanone from Cremastra appendiculata. Planta Med., v.70, n.2, p.171-173, 2004.

SIDDIQUI, A.A.; ALI, M. Practical pharmaceutical chemistry. 1.edn. New Delhi: CBS Publishers and Distributors, 1997. p.126-131.
SIDWELL, W.; TAMM, C. The homo-isoflavones II1). Isolation and structure of 4'-o-methyl-punctatin, autumnalin and 3, 9-dihydro-autumnalin. Tetrahedron Lett.,v.11, n.7, p.475478, 1970.

SILAYO,A.; NGADJUI, B.T.; ABEGAZ, B.M. Homoisoflavonoids and stilbenes from the bulbs of Scilla nervosa subsp.Rigidifolia. Phytochemistry, v.52, n.5, p.947$955,1999$.

TAMM, C. Homo-isoflavones, a new series of natural products. Arzneim. Forsch., v.22, n.10, p.1776-1784, 1972.

VOLAK, J.; STODOLA, J. Pharmaceutical plants, culturing and taking methods and explanation of 256 plant color slides. Translated by SAED, Z. 2.ed. Tehran: Ghoghnus Pub., 1995.

WINNICKA, K.; BIELAWSKI, K.; BIELAWSKA, A. Cardiac glycosides in cancer research and cancer therapy. Acta Pol. Pharm., v.63, n.2, p.109-15, 2006.

YASUDA, S.; NISHIDA, Y.; WADA, K.; AKIYAMA, D.; TOYOHISA, D.; TANAKA, T.; IGOSHI, K.; ONO, M. Anti-inflammatory and antioxidative effects of a methanol extract from bulbs of Scilla scilloides. Biosci. Biotech. Biochem., v.77, n.7, p.1569-1571, 2013.

Received for publication on $07^{\text {th }}$ December 2014 Accepted for publication on $24^{\text {th }}$ June 2015 
